\title{
Human Resource Management Practices and Employee Retention
}

\author{
Archana Yadav \\ Assistant Professor, College of Vocational Studies (University of Delhi), Delhi, India \\ E-mail: archanayadav2008@gmail.com
}

\begin{abstract}
The study aims to assess the predicting role of human resource management (HRM) practices in retaining employees in NTPC Ltd. The company has been successful not only in attracting the best talent in the market, but also in retaining them, according to NTPC's annual reports from $2013-17$, attrition rate was between $.93 \%$ to $1 \%$ of the Middle Executive. NTPC is a leader not only in the power industry, but also in the market due to its robust HRM practices. Training and development emerged as the most prominent HRM practice during the study, which is also considered the backbone of NTPC Ltd. The company maintains a dedicated Knowledge sharing centre located in Noida, known as the 'Power Management Institute' (PMI) which is a world-class learning centre, has collaborated with best institutes in the world and train employees at all levels from entry level to top executive level with 'planned intervention '. Data was obtained from NTPC's publications maintained in the form of annual reports and 'Power Management Institute 'annual calendars for the previous five years. A survey was conducted across various plants of NTPC on Middle- Level Executive on human resource practices which are followed in NTPC. HRM practices examined in this study are Security, training and development, quality of work life, compensation, career advancement, Promotion, award and rewards, and work-life balance. Findings indicate that Training and Development and Compensation are the most significant human resource practices in retaining employees and Promotion is the least significant HRM Practice in retaining employees at NTPC Ltd. Keywords: Employee Retention, Human Resource Management Practices NTPC Ltd., Training and Development.
\end{abstract}

\section{INTRODUCTION}

NTPC Ltd is the pioneer in the power sector in India, not just in transmission and distribution of power yet additionally in Training and Development. No other power plant in India can match the robust and world-class training provided by NTPC at all levels of hierarchy. The company has been successful not only in attracting the best talent in the market but also to retain them successfully. Apart from various significant human resource management practices 'training \& development' stand out as the most prominent HRM practice but also the backbone of the enterprise. Vision of the Company is 'To enable its people to be a family of committed world-class professionals, creating a learning organization. NTPC holds an exceptional reputation for attracting, retaining, and motivating its workforce which works as the company's competitive advantage. The learning activities are being driven by Power Management Institute (PMI) at the corporate level, six Regional Learning Institutes (RLIs) located in six large power stations of NTPC and Employee Development Centers (EDCs)located in all power projects and stations. EDCs take care of training requirements of non-executives and junior level executives. RLIs look after the training needs of middle and senior-level executives at regional level. PMI Noida is the apex Corporation Centre as the apex learning. PMI has over the years, trained not only NTPC's professionals, but also professionals from the State Power Utilities and other private sector power companies in diverse areas of technical and managerial disciplines. PMI has, entered into an institutional collaboration like Indian Institute of Management, Ahmadabad (IIMs), Management Development Institute (MDI) Gurgaon, the Harvard management for e-learning, IIT -Delhi, Boccioni University, Italy, IMD, Lausanne, Switzerland, and anymore.

NTPC Ltd is corporate responsible citizen, and contributed to the society in the area of gender equality , empowering women setting up homes and hostels for orphans and women, old age homes, day care centers, for senior citizens, drinking water, education, and health NTPC has been conferred various awards in area the of Corporate Governance such as ASSOCHAM Corporate Governance Excellence Award - 2014-15 for Listed Companies in the PSU category in recognition for outstanding governance practices undertaken by the Company. 'Golden Peacock Global Award for Excellence in Corporate Governance’ by World Council for Corporate Governance for the year 2014. This award was also received by the Company during the years 2007, 2009, and 2012. Award for Excellence in 2011 Good Corporate Citizen Award by $\mathrm{PhD}$ Chamber of Commerce and Industry. 'ICSI National Award for Excellence in Corporate Governance-2009’by the Institute of Company Secretaries of India.

\section{RESEARCH METHODOLOGY}

\section{A. Research Unit}

NTPC Ltd was chosen as a research unit to conduct a study of significant Human Resource Practices in retaining Employees.

\section{B. Research Objectives}

1. To analyze Human Resource Practices followed by NTPC Ltd. 
2. To examine which Human Resource Practices are significant in Retaining Employees

\section{Methods / Procedure and Data Collection}

Permission was obtained from NTPC's HR Department to conduct research in their plants. Research was conducted in a few rounds. The first round of data collection involved acquiring secondary data which included primarily two sources (I) NTPC's annual reports (II) Program calendar by Power Management institute which is the apex center of NTPC learning. Other sources of secondary data included Research Articles, Reports, and Reviews.

HR department extended best support possible in the execution of research work by providing a dedicated staff to aid related to the research work, motivating their executives to participate in the research process. The survey was conducted on 500 middle-level executives. The questionnaire was prepared on three-level responses. Two Questionnaires were prepared, one by using Google - docs, and the other in printed hard copy form for distribution by hand in the second round of data collection. The data collection process was complete in a few rounds, the firstround response was cold, subsequent follow-ups were made with informal discussions which included personal meetings and helping the executives to fill up the questionnaires in a few rounds the data collection process was complete.

Data were collected from both primary and secondary sources. The primary data were collected through a survey. A questionnaire that included both close-ended and openended questions. Close-ended questions were rated on five scale responses. The secondary data were acquired by the publications maintained by NTPC, their annual Reports, yearly Power Management Institute calendar which is the official publication source of the training and learning programs conducted by the organization, maintained by their dedicated research cell. The sample size was 500 employees.

\section{Research Instrument}

The Survey was conducted by a questionnaire which included Questions based on a three-level Likert scale responses where level 1 denotes the least score- Highly Insignificant human resource practices, level 2 denotes Midway/Indifferent attitude, level 3 denotes the highest level of significance of human resource practices.

\section{REVIEW OF LITERATURE}

Munish \& Agarwal (1990) asserted that there is no single factor responsible for job retention rather it is determined by a cluster of factors such as compensation, supervision, appreciation, challenging work, promotion, training and development, work environment, work-life balance, communication. Tangthong \& Rojniruntikul (2014) reveals a strong correlation between HRM practices and employee retention showed that three human resource practices such as career development, reward and recognition, and health and safety have a positive and significant impact on employee retention. Zhang \&Talat's (2016) study conducted in Austria, Hungary involving 1649 managers concluded Selective Staffing, Intensive training \& development, Extensive Compensation Benefits, and Performance Appraisal methods to be High- performance work practices.NgEric.et. al (2016) study conducted on 278 individuals in the Malaysian University concluded that there is a highly significant relationship between the factors of Training, Compensation and Appraisal and Retention and engagement of employees.

Kwenin (2012) Employee Rewards, Recognition Programs, understanding, appropriate motivational techniques help in contributing to the Retention of Employees. Milkovich \& Newman (2016) considered compensation to be the most important factor in job retention. Christeen.G (2016) stressed on eight retention factors, management, conducive work environment, development opportunities, relationship with pees, autonomy, compensation, job design, and worklife balance. Allen \& Shanock (2013) emphasized on relationships with colleagues to the key factor as retention balance. Munish \& Agarwal.R. (2013) Training and development, Recruitment and selection Compensation, and incentive policies are significant to Employee Retention.

Haider, Akhtar, Rasli \& Yusoof (2015) research confirmed that effective HR practices such as Training, development, Compensation, Organizational culture have a direct and positive relationship with Employee retention Mansoor (2015) examined the effect of reward and compensation on employee retention and engagement study showed that there is a positive and significant influence of career development techniques on employee retention and engagement. Elshammar \& Hammad (2015) Review result found that employee Training \& Development, Supervisor's support. Team \& Co-worker. Chew, J. C. (2004) pointed out eight retention factors that influence the retaining of employees.

factors consisted of two categories of practices: HR factors person organizational fit, remuneration, reward and recognition, training and career development, challenging job opportunities and Organizational factors leadership behavior, company culture and policies, teamwork relationship and satisfactory work environment, However Habib, Aslam, Hussain, Yameen, Ibrahim(2014)concluded that there is a positive correlation between the impact of Organizational Culture on Employee Commitment, Job Satisfaction, and Employee Retention. Similarly, a study conducted by Chukwuha \& Nwakoby(2018) indicated that there is a weak and insignificant effect of HRM practices on employee retention. Imna \&Hassan (2015) found no significant influence of Training and development on employee retention, however, when training and development are linked with career development, there is a positive and significant influence on employee retention. 


\section{HUMAN RESOURCE PRACTICES AT NTPC LTD.}

\section{A. Security}

This is being taken care of by deploying CISF at all units of the Company as per norms of the Ministry of Home Affairs. Concrete steps are being taken for upgrading surveillance systems at all projects/ stations by installing state- of-the-art security systems. A $24 \times 7$ Security Operation Centre (SOC) is in operation where round the clock monitoring of all external and internal data traffic is being analyzed with the latest tools monitored through SOC and the latest threat management tools are being applied to prevent any cyber-attack or data theft.

\section{B. Training and Development}

The learning activities are being driven by a comprehensive infrastructure comprising the NTPC Power Management Institute (PMI) at the corporate level, six Regional Learning Institutes (RLIs) located strategically in six large power stations of NTPC and Employee Development Centers (EDCs) located at almost all power projects and stations. At the foundation of the learning structure of the Company are the EDCs. The EDCs take care of training requirements of non-executives and junior level executives at the projects and stations. The training requirements of middle and senior level executives are catered to by RLIs at regional level and PMI, Noida at the corporate centre as the apex learning centre launched the Harvard Management or e-learning modules with 2000 licenses made available to middle level executives across the company.

\section{Level-Wise Planned Interventions}

NTPC conducts specially designed leadership and management development programs at certain identified stages of the careers of all the executives across all the functions in order to build these competencies. These specific program modules include strategic thinking, communication skills, negotiation skills, risk management, conflict resolution, boundary management, corporate governance, decision making, understanding of finance, commercial and regulatory issues, team building, contract labour management and other areas of practical significance. NTPC PMI also conducts Employee Development Programs for non-executives posted at our corporate Centre. These programs are called "Planned Intervention". A schematic representation of these interventions is depicted in Figure 1.

\section{Enhancing Technical Expertise}

Programs are designed to enhance technical knowledge and competencies of the participants. The emphasis is on new and emerging areas and advances in technologies. ELearning Video and Web Conferencing to Deliver Programs at Participants' Doorsteps. Learning through these IT and communications enabled modes allows participants to learn at their workplace, at their own pace and convenience. Such learning has eliminated the opportunity cost of participants' absence from their workplace. This has also done away with the hassles of travel and reduced the expenditure on training. A few programs in this category are Advanced Excel, Cryptography, Control Valves and Actuators, Earthling, Grounding and Shielding for instrumentation engineers, import management and customs clearance, roof top solar plant for buildings etc.

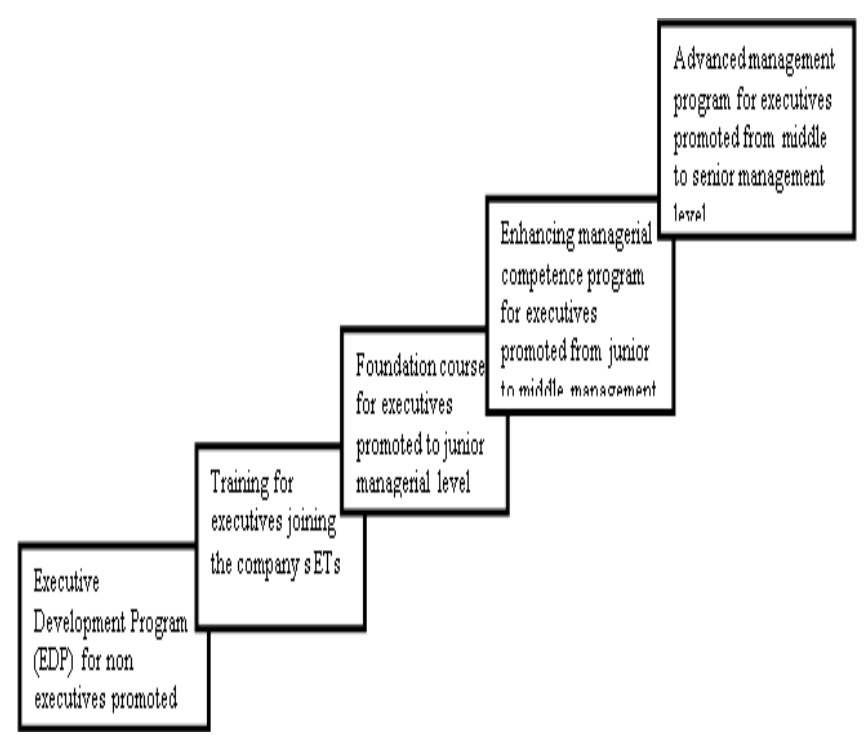

Fig.1 (Source) NTPC Ltd. power management institute calendar 2016-17

\section{E. Collaborating with the Best in the World}

NTPC has entered mutually beneficial partnerships with premier educational and consulting institutions to develop learning synergies. Over the years, our international learning associates include The Wharton School, University of Pennsylvania, US, University of Maryland, US ,ESCP Europe, IMD, Lausanne, Switzerland ,Bocconi University Italy Nanyang Technological University Singapore, SP Jain School of Global Management Singapore, NTPCs learning associates in the country include, IIM Ahmadabad, IIT Delhi, Tata Institute of Social Sciences (TISS) Mumbai, Administrative Staff College of India (ASCI) Hyderabad, XLRI Jamshedpur ,IIM Indore, MDI- Gorgon, Birla Institute of Management Technology (BIMTECH), XISS Ranchi, International Management Institute (IMI) Delhi, National Power Training Institute (NPTI), Educational Consultants India Limited (EdCIL), Tata Management Training Centre Pune.

\section{F. Successive Leadership}

It is well recognized that leadership is needed at all the levels in the organization - junior, middle and apex levels. NTPC has developed a series of leadership development interventions at critical transition levels in the organization 
pyramid. The identified transaction points are: From junior executive to junior manager, from junior to middle management, from middle to senior management. Business leaders groomed in NTPC are occupying leadership positions in many enterprises in the power sector. This is a concrete proof of the effectiveness of our approach to leadership development.

\section{G. Providing Research and Consultancy Solutions}

NTPC PMI offers consultancy services in Human Resource Management areas like Manpower Planning, Organizational Behavior, Training Needs Analysis, HR Systems and Manuals, Organization Development and other areas NTPC PMI have conducted various assignments for state power utilities in the wake of reforms and restructuring programs in the power sector. We are also engaged in research in several techno-managerial areas related to the power sector through our Senior Research Fellowship Programs. NTPC hassteered several organizational development interventions like Team building, Communication dynamics, Project management, Knowledge management.

\section{H. Social Welfare}

NTPC Promotes gender equality, empowering women, by setting up homes and hostels for women and orphans, setting up old age homes, day care centers and such other facilities for senior citizens and measures for reducing inequalities face by socialite and economically backward groups.

\section{Post-Retirement Benefits}

(a) Medical Facility (PRMF)

The Group has a Post-Retirement Medical Facility (PRMF), under which the retired employees and their spouses are provided medical facilities in the Group's hospitals/empanelled hospitals.

\section{(b) Gratuity \& Pension}

Every employee who has rendered continuous service of five years or more is entitled to gratuity at 15 days' salary (15/26 X last drawn basic salary plus dearness allowance) for each completed year of service subject to a maximum of Rs. 0.10 crore on superannuation, resignation, termination or disablement on death.

\section{J. Whistle Blower Policy}

The Company has a Board approved 'Whistle Blower Policy' for directors and employees to report to the management concerns about unethical behavior, actual or suspected fraud or violation of the company's code of conduct or ethics policy. It also provides safeguards against victimization of employees, who avail the mechanism and for direct access to the Chairman of the Audit Committee. No personnel of the company had been denied access to the audit committee. The Whistle Blower Policy is available at the weblink: http://www.ntpc.co.in/sites/default/files/ downloads/ WhistleBlowerPolicy.pdf.

\section{K. Corporate Social Responsibility}

NTPC commits itself to contribute to the society promoting inclusive growth and environmental sustainability. Focus areas of NTPC's CSR \& Sustainability activities are Health, Sanitation, Drinking Water, Education, Capacity Building, Women Empowerment, Social Infrastructure Development, support to Physically Challenged Person (PCPs), and activities contributing towards Environment Sustainability. more than 400 villages and more than 360 schools have been benefitted by NTPC various CSR initiatives at different locations. These CSR initiatives have touched the lives of around 10 lakh people in one or the other way, residing at remote locations. special thrust had been given to the "Clean Water and Sanitation"

TABLE I CORPORATE SOCIAL RESPONSIBILITY

\begin{tabular}{|c|l|c|}
\hline $\begin{array}{c}\text { Sl. } \\
\text { No. }\end{array}$ & \multicolumn{1}{|c|}{ Activity } & $\begin{array}{c}\text { CSR Spend } \\
\text { 2016-17 } \\
\text { (Rs. Crore) }\end{array}$ \\
\hline 1 & $\begin{array}{l}\text { Swachh Vidhyalay } \\
\text { Abhiyaan }\end{array}$ & 35.73 \\
\hline 2 & Healthcare \& Sanitation & 55.52 \\
\hline 3 & $\begin{array}{l}\text { Education \& Skill } \\
\text { development }\end{array}$ & 60.45 \\
\hline 4 & Rural Development & 51.30 \\
\hline 5 & Environment & 35.33 \\
\hline 6 & Drinking Water & 9.36 \\
\hline 7 & Sports & 1.90 \\
\hline 8 & Capacity Building & 11.39 \\
\hline 9 & $\begin{array}{l}\text { Protection of National } \\
\text { Culture and Heritage }\end{array}$ & 0.82 \\
\hline 10 & Other CSR Activities & 16.01 \\
\hline 11 & Grand Total & 277.81 \\
\hline
\end{tabular}

Source: NTPC Ltd. Annual Report 2016-17, p. 149

\section{RESULTS AND DISCUSSIONS}

TABLE II TRAINING \& DEVELOPMENT

\begin{tabular}{|l|c|c|c|c|}
\hline $\begin{array}{l}\text { Human } \\
\text { Resource } \\
\text { Practices }\end{array}$ & Insignificant & Neutral & Significant & Total \\
\hline $\begin{array}{l}\text { Training\& } \\
\text { development }\end{array}$ & 67 & 67 & 367 & 500 \\
\hline $\begin{array}{l}\text { Quality of } \\
\text { work life }\end{array}$ & 100 & 83 & 317 & 500 \\
\hline Compensation & 52 & 86 & 362 & 500 \\
\hline $\begin{array}{l}\text { Education-up } \\
\text { gradation }\end{array}$ & 111 & 93 & 296 & 500 \\
\hline $\begin{array}{l}\text { Promotion } \\
\text { Policy }\end{array}$ & 200 & 100 & 200 & 500 \\
\hline $\begin{array}{l}\text { Work life } \\
\text { balance }\end{array}$ & 180 & 80 & 240 & 500 \\
\hline $\begin{array}{l}\text { Awards \& } \\
\text { Rewards }\end{array}$ & 86 & 155 & 259 & 500 \\
\hline
\end{tabular}




\section{A. Training \& Development}

NTPC has Robust Training Mechanism (Power Management Institute) which is reflected in the survey, 367 respondents Which is are $73.4 \%$ middle level executives in NTPC consider Training \& Development programs to be highly significant HRP to employee retention. Even Informal discussions revealed that Training \& Development mechanism is backbone In NTPC and is considered as a highest motivating factor and most significant Human Resource Practices for retention.

\section{B. Compensation}

Ranks next after Training \& Development in the list of human resource practices in significance to employee retention. $72.4 \%$ of middle- level executives consider compensation to be significant HRP to their job retention.

\section{Quality of Work-Life}

Ranks after Compensation as most significant HRP to retaining employees of middle level executives at NTPC Ltd.63.4\% middle level executives considered QWL to be significant to them.

\section{Work- Life Balance}

$48 \%$ of middle- level executives considered WLB to be a significant factor while,36\% did not perceive it to be significant to their retention and16\% were neutral about it. Informal discussions indicated that WLB was not a popular HRP among Executives.

\section{E. Promotion Policy}

Emerged as the least popular human resource practices to employee retention in NTPC Ltd. $40 \%$ executive's s considered promotion policy to be insignificant, $20 \%$ were neutral. It was observed in personal interviews, discussions, and meetings with the executive's promotion policy seemed to be least popular since promotion policy in NTPC is associated with Transfer which is not taken well by many.

\section{CONCLUSION}

NTPC has robust Human resource practices, it is operating at the best efficiency and productivity. NTPC takes pride in its highly motivated and competent Human Resource that has contributed its best to bring the Company to its present heights. Training \& Development, Compensation, Quality of Work-life are the most significant practices which are responsible for retaining employees, and Promotion and work-life balance is at the bottom in the rank of significance. The attrition rate of the NTPC executives (including Executive Trainees and those posted in Subsidiaries and JVs) during the year was .93\%. NTPC's excellent Human resource practices which take care of all employee needs from basic needs such as safety to growth and Development, Recreational, providing an excellent quality of life. NTPC has a world-class learning Centre called as PMI -Power Management Institute, which is a strength and pillar for NTPC's Training \& development for employees at all levels. PMI has helped in the development of one of the best cadres of energy professionals in the world. Training \& Development is perceived to be the most significant Human Resource Practice in NTPC responsible for its Employee Retention and considered pillar strength and backbone of NTPC Ltd.

\section{REFERENCES}

[1] Allen, D.,Shanock,L.(2013).Perceived Organizational support and embeddedness as key mechanisms connecting Socialization tactics to commitment and turnover among new employees :Journal of Organizational Behaviour, 34(3), DOI: 10.1002/job.1805.

[2] Chew, J. C. (2004). The Influence of Human Resource Management Practices on the Retention of Core Employees of Australian Organization: An Empirical Study. Perth: Murdoch University.

[3] Crossley, C. D., Bennett, R. J., Jex, S. M., \&Burnfield, J. L. (2007) Development of a Global measure of Job Embeddedness and Integration into a Traditional model of voluntary turnover Journal of Applied Psychology, 92(4), 1031-1042.

[4] Das, B L., Baruah.M.S.(2013). Employee Retention: A Review of Literature. IOSR Journal of Business and Management, 14(2) 08-16, www.iosrjournals.org. DOI:10.9790/487X-1420816

[5] Gharib.M.N., Kahwaji.A.T., Elrasheed.M.O.(2017). Factors Affecting Staff Retention Strategies Used in Private Syrian Companies during the Crisis: International Review of management and Marketing. (2), 202-206.www.econjournals.com

[6] Imna, G.,Hassan,Z.(2015).Influence of Human Resource Management practices on Employee Retention in Maldives Retail Industry: International Journal of Accounting \& Business Management www.ftms.edu.my/journals/index.php/journals/ijabm 3(1),April,2015ISSN:2289-4519DOI: 10.24924/ijabm/2015.04/v3.iss1/50.80

[7] Kontor. M.F. (2019). The Effects of Person-Organization Fit and Employee Commitment. The Mediating Role of Organizational Culture. Archives of Business Research,7(10),121-131. DOI:10.14738/abr.710.7202.

[8] Kossivi, B., Kalgora.B., Xu,ming.(2016).study on Determining Factors of Employee Retention. Open Journal of Social Sciences,4(5), 261-268 04(05):261-268 DOI: 10.4236/jss.2016.45029

[9] Kwenin.D., Muathe.S., Nzulwa.R.(2013). European Journal of Business and Management, 5(12), www.iiste.org.

[10] Milkovich,G.M.,Newman., J.M. (2016). Study on determining factors of Employee Retention: Open Journal of Social Sciences, 4, 261-268. http://www.scirp.org/journal/jsshttp://dx.doi.org/10.4236/jss.2016.45 029

[11] Munish \& Agarwa,, R..(2017). A Review Literature. International Journal of BRIC Business Research IJBBR, 6(1).

[12] Ng, Eric., Hao,LZ., Hong,C . (2012). Effectiveness of Human Resource Management Practices on Employee Retention in Institute of Higher learning: - A Regression Analysis: International Journal of Business Research and Management (IJBRM),3(2)

[13] NTPC Ltd (2016-17).41st Annual Report NTPC Ltd: NTPC scope Complex, New Delhi, 45.

[14] NTPC Ltd (2016-17).41st Annual Report NTPC Ltd.: NTPC Scope Complex, New Delhi, 62.

[15] NTPC Ltd. (2016-17) .41st) Annual Report (2016-17) NTPC Ltd. Scope Complex Delhi, 79.

[16] NTPC Ltd. (2012-13) Power Management Institute Calendar 2016-17: NTPC Ltd. Scope Complex, New Delhi, 1-5..

[17] NTPC Ltd (2016-17.,41 ${ }^{\text {st }}$ Power Management Institute Calendar, NTPC Scope Complex, New Delhi, 12.

[18] NTPC Ltd (2016-17)41st. Power Management Institute Calendar, NTPC Scope Complex, New Delhi, 8.

[19] NTPC Ltd (2016-17).41st Power Management Institute Calendar, NTPC Scope Complex, New Delhi,17. 
[20] NTPC Ltd (2016-17).41st Annual Report, NTPC Scope Complex, New Delhi, 149.

[21] NTPC Ltd. (2016-17).41st Annual Report (2016-17) NTPC Ltd. Scope Complex Delhi, 65.

[22] NTPC Ltd. (2016-17) .41stAnnual Report (2016-17) NTPC Ltd. Scope Complex Delhi, 48.

[23] NTPC Ltd. (2016-17).41st Annual Report (2016-17) NTPC Ltd. Scope Complex Delhi, 145.

[24] NTPC Ltd (2016-17).41st Annual Report NTPC Ltd., Power Management Institute Noida, -45-46.
[25] NTPC Ltd (2016-17).41st Annual Report NTPC Ltd., Power Management Institute Noida, 144.

[26] Tangthong, S.Trimetsoontor .J., Rojniruntikul, N. (2014). HRM Practices and Employee Retention in Thailand-A Literature Review," International Journal of Trade, Economics and Finance $V$ 5, (2), 162-166.

[27] Zhang, J.Akhtar.N.M.,Bal, P.M., Zhang, Y ., Talat ,U. (2016).How Do High-Performance Work Systems Affect Individual Outcomes: A Multilevel Perspective: Frontiersin Pshychology, Publishedonline, 2018 Apr 24 doi: 10.3389/fpsyg.2018.00586. 